\title{
Thermococcus barophilus sp. nov., a new barophilic and hyperthermophilic archaeon isolated under high hydrostatic pressure from a deep-sea hydrothermal vent
}

\author{
Viggó Thór Marteinsson, ${ }^{1} \dagger$ Jean-Louis Birrien, ${ }^{1}$ \\ Anna-Louise Reysenbach, ${ }^{2}$ Marc Vernet, ${ }^{1}$ Dominique Marie, ${ }^{1}$ \\ Agata Gambacorta, ${ }^{3}$ Paul Messner, ${ }^{4}$ Uwe B. Sleytr ${ }^{4}$ and Daniel Prieur ${ }^{1,5}$
}

Author for correspondence: Viggó Thór Marteinsson. Tel: +354 5707213. Fax: + 3545707111.

e-mail: viggo@iti.is

1 Station Biologique, CNRS, UPR 9042, BP 74, 29681 Roscoff cedex, France

2 Rutgers University Institute for Marine and Coastal Sciences, Cook College, New Brunswick, NJ 08903. USA

3 Istituto per la Chimica di Molecole di Interesse Biologico, CNR, via Toiano 6, 80072 Arco Felice, Napoli, Italy

4 Zentrum für Ultrastrukturforschung und Ludwig Boltzmanninstitut für Molekulare Nanotechnologie, Universităt für Bodenkultur, A-1180 Wien, Austria

5 Université de Bretagne Occidentale, Brest, France

\begin{abstract}
A novel barophilic, hyperthermophilic, anaerobic sulfur-metabolizing archaeon, strain MP' (T = type strain), was isolated from a hydrothermal vent site (Snakepit) on the Mid-Atlantic Ridge (depth, $3550 \mathrm{~m}$ ). Enrichments and isolation were done under $40 \mathrm{MPa}$ hydrostatic pressure at $95^{\circ} \mathrm{C}$. Strain MPT was barophilic at 75, 80, 85, 90, 95 and $98^{\circ} \mathrm{C}$, and was an obligate barophile between 95 and $100{ }^{\circ} \mathrm{C}\left(T_{\max }\right)$. For growth above $95^{\circ} \mathrm{C}$, a pressure of 15.0-17.5 MPa was required. The strain grew at 48-95 ${ }^{\circ} \mathrm{C}$ under atmospheric pressure. The optimal temperature for growth was $85^{\circ} \mathrm{C}$ at both high $(40 \mathrm{MPa})$ and low $(0.3 \mathrm{MPa})$ pressures. The growth rate was twofold higher at $85^{\circ} \mathrm{C}$ under in situ hydrostatic pressure compared to at low pressure. Strain MPT cells were motile, coccoid, $0.8-2.0 \mu \mathrm{m}$ in diameter and covered by a hexagonal S-layer lattice. The optimum $\mathrm{pH}$ and $\mathrm{NaCl}$ concentration for growth at low pressure were 7.0 and $20-30 \mathrm{~g} \mathrm{I}^{-1}$, respectively. The new isolate was an obligate heterotroph and utilized yeast extract, beef extract and peptone for growth. Growth was optimal in the presence of elemental sulfur. Rifampicin and chloramphenicol inhibited growth. The core lipids consisted of a major archaeol and a complex lipid pattern consisting of a major phospholipid. The DNA G+C content was $37.1 \mathrm{~mol} \%$. Sequencing of the 165 rRNA gene revealed that strain MP' belonged to the genus Thermococcus and it is proposed that this isolate should be designated as a new species, Thermococcus barophilus.
\end{abstract}

Keywords: archaea, barophile, Thermococcus, hyperthermophile, deep-sea vent

\section{INTRODUCTION}

With the discovery that extremely thermophilic microbial communities inhabit deep-sea hydrothermal vents, numerous strains of hyperthermophilic archaea have been isolated from such environments (Prieur et al., 1995). All of these isolates were obtained by selective cultivation at atmospheric pressure $(0 \cdot 101 \mathrm{MPa})$. Few attempts to enrich for isolates under in situ pressure have yielded mixed cultures of hyper-

\footnotetext{
†Present address: Department of Biotechnology, Technological Institute of Iceland, Keldnaholt, IS-112 Reykjavik, Iceland.

The GenBank accession number for the $16 \mathrm{~S}$ rRNA sequence of strain MP ${ }^{\top}$ is U82237.
}

thermophiles (Reysenbach \& Deming, 1991) and, until now, no isolates have been sustainable in pure culture.

The response of deep-sea psychrophilic bacteria to hydrostatic pressure has been well-documented by Yayanos (1986), while much less information exists on the response of thermophiles to pressure. Pressure can have a stimulating effect on the growth of one isolate and virtually no effect on another. Barophilic psychrophiles tend to be found at or below $2000 \mathrm{~m}$ (Yayanos, 1986), while the upper layers are dominated by barotolerant species (Jannasch \& Wirsen, 1984). A depth of $6350 \mathrm{~m}$ appears to be the shallowest depth for isolation of obligate barophiles (Yayanos, 1986).

Several studies of hyperthermophilic isolates grown under elevated pressure have been reported (Erauso et 
al., 1995; Holden \& Baross, 1995; Jannasch et al., 1992; Marteinsson et al., 1997; Miller et al., 1988; Nelson et al., 1991, 1992; Pledger et al., 1994; Reysenbach \& Deming, 1991). However, not all of these hyperthermophilic strains tested under highpressure conditions showed a barophilic response at their in situ pressures. Barotolerant (Reysenbach \& Deming, 1991) and barosensitive (Jannasch et al., 1992) strains have been reported and, in some cases, the pressure response was temperature dependent (Deming \& Baross, 1993; Jannasch et al., 1992).

The presently known barophilic hyperthermophiles were all obtained from hydrothermal vent sites, located at a depth of at least $2000 \mathrm{~m}$. These micro-organisms grew better under high pressure or near their in situ pressure and their optimal and maximal temperatures were shifted by several degrees under these conditions. During the French-American 'MAR93' cruise in June 1993 on the Mid-Atlantic Ridge, a new hydrothermal site located deeper than most other hydrothermal vent sites was explored. In the present study, a new hyperthermophilic archaeon was isolated near its in situ pressure and the effect of pressure on its temperature range for growth was investigated.

\section{METHODS}

Reference strains. 'Thermococcus litoralis' DSM 5474 and Thermotoga maritima DSM $3109^{\mathrm{T}}(\mathrm{T}=$ type strain) were obtained from the Deutsche Sammlung von Mikroorganismen und Zellkulturen (DSMZ). 'Pyrococcus abyssi' GE5 ${ }^{\mathrm{T}}$ was obtained from our laboratory in Roscoff, France.

Collection of samples and storage. Samples were collected during the oceanographic cruise 'MAR93' in June 1993, organized by Institut National des Sciences de l'Univers (INSU) and Woods Hole Oceanographic Institution (WHOI). Active and non-active chimney rocks and hot fluids were collected on the Mid-Atlantic Ridge at a depth of $3550 \mathrm{~m}$ from Snakepit $\left(23^{\circ} 224118 \mathrm{~N}, 44^{\circ} 564984 \mathrm{~W}\right)$ by the American submersible Alvin. Aboard the ship R.V. Jean Charcot, solid samples were immediately transferred into an anaerobic chamber and then into $10-30 \mathrm{ml}$ sterile glass syringes (Ultrafit; Heinke-Sass-Wolf) that were sealed by plunging needles into rubber stoppers. The syringes were filled with sterile, reduced artificial seawater (Marteinsson $e t$ $a l ., 1995)$ before the cut pistons were put in place and the gas phase was expelled prior to tightening the seal on each syringe. Syringes were transferred into high-pressure vessels and pressurized with cold water up to $40 \mathrm{MPa}$ hydrostatic pressure. Samples were kept under pressure and at $4{ }^{\circ} \mathrm{C}$ until enrichment.

Enrichments and isolation under in situ hydrostatic pressure. All culturing manipulations preceding pressure experiments were performed in an anaerobic chamber. Samples, stored at $4{ }^{\circ} \mathrm{C}$ under $40 \mathrm{MPa}$ hydrostatic pressure, were depressurized and $0.5 \mathrm{ml}$ rock suspensions and hydrothermal fluids were transferred into $10 \mathrm{ml}$ syringes. Each syringe contained either YPS medium (Marteinsson et al., 1995) buffered with PIPES buffer (Sigma; $7.0 \mathrm{~g}^{-1}$ at $\mathrm{pH} \mathrm{6.8)}$ (designated hereafter as YPS-20) or modified Thermotoga medium (Huber et al., 1986) which had the following composition $\left(1^{-1}\right.$ distilled water): $0.96 \mathrm{~g}$ PIPES buffer, $2.4 \mathrm{~g} \mathrm{NaCl}, 0.16 \mathrm{~g}$
$\mathrm{MgSO}_{4} .7 \mathrm{H}_{2} \mathrm{O}, 0.016 \mathrm{~g} \mathrm{NH}_{4} \mathrm{Cl}, 0.04 \mathrm{~g} \mathrm{CaCl}_{2} .2 \mathrm{H}_{2} \mathrm{O}, 0.16 \mathrm{~g}$ yeast extract (Difco) and $10 \mathrm{mM}$ glucose. The $\mathrm{pH}$ of the medium was adjusted to 6.8 . Sulfur $(0 \cdot 1 \mathrm{~g})$ was added to the syringes, which had been sealed by plunging needles into rubber stoppers, before media and samples were dispensed in the syringes. Finally, the pistons were put in place and the gas phase was expelled prior to tightening the seal on each syringe. The syringes were then transferred into the high pressure and temperature incubation system, custom-built by Top Industrie (Industrial zone 'Le Plateau de Bière', Dammarie-les-Lys, France), pressurized to $40 \mathrm{MPa}$ and heated to $95^{\circ} \mathrm{C}$ (Marteinsson et al., 1997). The isolate was purified under $40 \mathrm{MPa}$ by six serial dilutions at $95^{\circ} \mathrm{C}$. Low pressure enrichments were performed in serum bottles at $95{ }^{\circ} \mathrm{C}$.

Cellular protein extraction and PAGE. Whole-cell proteins were extracted as described by Marteinsson et al. (1995). Equal protein concentrations from samples were loaded on $5-20 \%(\mathrm{w} / \mathrm{v})$ gradient polyacrylamide-SDS gels $(5 \%, \mathrm{w} / \mathrm{v}$, stacking gel) (Laemmli, 1970).

Determination of growth parameters under hydrostatic pressure. To determine growth rates at different temperatures under high and low pressures, cells were grown in $10 \mathrm{ml}$ syringes containing $10 \mathrm{ml}$ YPS-20 medium. The syringes were loaded anaerobically in an anaerobic chamber with $10 \mathrm{ml}$ medium and inoculated with $0.2 \mathrm{ml}$ culture in lateexponential phase grown under $40 \mathrm{MPa}$ pressure at $85^{\circ} \mathrm{C}$. Samples were pressurized to the test pressure before heating the vessel ovens. Heating started at $22^{\circ} \mathrm{C}$ and it took approximately $30 \mathrm{~min}$ to obtain stable test temperatures $\left(75,80,85,90,95\right.$ and $\left.98^{\circ} \mathrm{C}\right)$. Each temperature was tested at high $(40 \mathrm{MPa})$ and low pressure $(0.3 \mathrm{MPa})$ in parallel experiments. Growth curves at the different temperatures were generated by cooling the pressurized vessels in a continuous flow of cool water for $2 \mathrm{~min}$ to approximately $50{ }^{\circ} \mathrm{C}$. The pressure decreased progressively with decreased temperature and the remaining pressure was released gently through a valve. Samples (approx. $0.4 \mathrm{ml}$ ) were immediately collected anaerobically and injected into venoject bloodcollecting tubes (Terumo) before repressurizing and reheating the syringes to the test temperature (approx. $30 \mathrm{~min}$ ). Each sample was processed in duplicate and was fixed immediately in $4 \%(\mathrm{v} / \mathrm{v})$ formaldehyde. At each time-point, analysis was performed in duplicate and, in some cases, the experiment was repeated.

Determination of maximum temperature for growth of the new isolate under hydrostatic pressure was performed in triplicate at 40 and $0.3 \mathrm{MPa}$. The minimal hydrostatic pressure required for growth above $95^{\circ} \mathrm{C}$ was estimated at $0.25 \mathrm{MPa}$ intervals. This experiment was performed in duplicate and repeated three times. In all cases, cells grown at high pressure were used as the inoculum.

Determination of growth parameters. Anaerobic procedures were performed as described by Balch \& Wolfe (1976). Standard YPS medium was used in all cultures unless otherwise stated. To determine the optimum $\mathrm{pH}$ and $\mathrm{NaCl}$ concentration, cells were grown in Hungate tubes $(27 \mathrm{ml}$; Bellco) containing $7 \mathrm{ml} \mathrm{YPS}$ medium and $\mathrm{N}_{2}$ at a pressure of $100 \mathrm{kPa}$ in the headspace. The YPS medium was modified with the following buffers (Sigma), all at $10 \mathrm{mM}$ : pH 3.5-4.5, no buffer; pH 5.0-6.0, MES buffer; pH 6.5-7.0, PIPES buffer; pH 7.5-8.5, HEPES; pH 9.0-10, no buffer. To determine the optimal salt requirement, YPS medium was prepared either without $\mathrm{NaCl}$ or supplemented with $\mathrm{NaCl}$. The effects of $\mathrm{pH}$ and salinity were determined in duplicate 
at $85^{\circ} \mathrm{C}$. Minimal growth temperature experiments were performed in $27 \mathrm{ml}$ Hungate tubes containing $5 \mathrm{ml}$ YPS medium with $\mathrm{N}_{2}$ in the headspace at $100 \mathrm{kPa}$ and incubated in aluminium heating blocks (Bioblock). The temperatures were monitored with temperature probes placed in control tubes. Cultures on plates were obtained on YPS medium solidified with Gelrite (Erauso et al., 1995). Plates were incubated in an anaerobic jar at $85^{\circ} \mathrm{C}$ (gas phase $\mathrm{N}_{2} / \mathrm{H}_{2} / \mathrm{CO}_{2} 90: 5: 5 ; 100 \mathrm{kPa}$ ) for $3 \mathrm{~d}$.

Determination of cell numbers. Growth was measured by either flow cytometry or microscopy. For flow cytometry, samples were fixed with $1 \%$ (v/v) glutaraldehyde for $20 \mathrm{~min}$ at ambient temperature before storage at $-80^{\circ} \mathrm{C}$. Cell DNA was stained with PicoGreen (Molecular Probes) at $37^{\circ} \mathrm{C}$ for $1 \mathrm{~h}$ with a mixture of RNase in TE buffer (Marie $e t$ al., 1996). The DNA-specific stain was used at a final concentration of $1: 1000$ of the commercial solution. Cells were enumerated by a FACsort flow cytometer equipped with a $488 \mathrm{~nm}$ laser, and samples were delivered at a calibrated rate of $28 \mu \mathrm{l}$ for 1-4 min. Forward and right-angle light scatter, as well as DNA fluorescence, were collected as LISTMADE files and processed with custom-designed software CYTOWIN (D. Vaulot, unpublished data).

For microscopy, cells were counted in a Petroff-Hausser chamber (depth, $0.02 \mathrm{~mm}$ ) using a light microscope (model BH2; Olympus) equipped with a phase-contrast oil immersion objective ( $\times 100$ magnification). A good correlation was found between microscopic and flow cytometric counts. Growth rates were calculated using linear regression analysis from three to five points along the logarithmic portions of the resulting growth curves.

Substrate utilization and culture conditions. Substrate utilization analysis was done in $27 \mathrm{ml}$ Hungate tubes containing $10 \mathrm{ml}$ medium. The tubes were inoculated with an exponentially growing culture at a final concentration of $5 \times 10^{5}$ cells ml ${ }^{-1}$ and incubated at $85^{\circ} \mathrm{C}$. All tests were performed in duplicate. Uninoculated medium was used as a negative control for each substrate and inoculated YPS medium (containing yeast extract and peptone) was used as a positive control. Growth was recorded after 2 and $7 \mathrm{~d}$. The ability of the $\mathrm{MP}^{\mathrm{T}}$ isolate to use single carbon sources for growth was tested on YPS medium without yeast extract and peptone. This basal medium was supplemented with one of the following carbon sources: starch, maltose, glycogen, sucrose and glucose to a final concentration of $0.5 \%(\mathrm{w} / \mathrm{v})$, while yeast extract, peptone, tryptone, pyruvate, casein hydrolysate, casein non-hydrolysate, beef extract, Casamino acids, succinate, propionate and acetate were present at a final concentration of $0.2 \%(\mathrm{w} / \mathrm{v})$. A filter-sterilized solution of vitamins $\left(10 \mathrm{ml} \mathrm{l}^{-1}\right)$ (Canganella et al., 1997) was added and $\mathrm{N}_{2}$ gas was used as the headspace gas. Nitrogen sources were tested in the absence of $\mathrm{NH}_{4} \mathrm{Cl}$ with pyruvate $(40 \mathrm{mM})$ added as the carbon and energy source in the mineral basal medium. Urea, thiourea, glutamate and gelatin were all tested at $0.2 \%(\mathrm{w} / \mathrm{v})$, while $\mathrm{NH}_{4} \mathrm{Cl}, \mathrm{KNO}_{3}$ and $\mathrm{KNO}_{2}$ were added at $20 \mathrm{mM}$ to the basal medium. The headspace contained $\mathrm{H}_{2} / \mathrm{CO}_{2}(20: 80)$.

Autotrophic growth under $\mathrm{H}_{2} / \mathrm{CO}_{2}(80: 20)$ was tested in the basal medium. To determine the ability of the isolate to grow in the absence of elemental sulfur $\left(\mathrm{S}^{\circ}\right)$, cells were cultured in YPS medium from which sulfur compounds had been omitted. The headspace gas was $\mathrm{N}_{2}$ or $\mathrm{H}_{2} / \mathrm{CO}_{2}(20: 80)$ in these experiments and titanium (III) citrate $(1 \mathrm{mM}$ final concentration) was used as reducing agent instead of $\mathrm{Na}_{2} \mathrm{~S} .9 \mathrm{H}_{2} \mathrm{O}$. Growth was determined by direct cell counts in a Petroff-Hausser chamber (depth, $0.02 \mathrm{~mm}$ ) with a phasecontrast microscope.

Antibiotic susceptibility. The sensitivity to antibiotics was tested at $150 \mu \mathrm{g} \mathrm{ml}^{-1}$ in YPS medium. Cells were inoculated at $80^{\circ} \mathrm{C}$ in Hungate tubes. Controls were performed with an antibiotic-sensitive bacterium, Thermotoga maritima, cultivated under the same conditions to demonstrate the efficiency of the antibiotic at $80^{\circ} \mathrm{C}$.

Electron microscopy. Preparation of cells for freeze-fracturing was carried out as described previously (Sleytr et al., 1988). Micrographs were taken with a model CM100 electron microscope (Philips) at an acceleration voltage of $80 \mathrm{kV}$.

Lipid analysis. The lipids were analysed in cultures grown at $85^{\circ} \mathrm{C}$ in 11 serum flasks at atmospheric pressure and incubated in ovens (Memmert). Lipids were extracted from dried cells according to De Rosa et al. (1983) and analysed by TLC. One-dimensional TLC was performed by eluting with chloroform/methanol $/ \mathrm{H}_{2} \mathrm{O}(65 / 25 / 4$ by vol.). Twodimensional TLC was developed with chloroform/ methanol $/ \mathrm{H}_{2} \mathrm{O}(65 / 25 / 4$ by vol.) followed by chloroform/ methanol/ethanol $/ \mathrm{H}_{2} \mathrm{O}(80 / 12 / 15 / 4$ by vol.) (De Rosa \& Gambacorta, 1994), and compared to lipid standards obtained from other archaea (Pley et al., 1991). The total lipid extract was hydrolysed in $1 \mathrm{M}$ methanolic $\mathrm{HCl}$ to cleave the polar head groups. The core lipids were identified by TLC as previously described (Trincone et al., 1988; Huber et al., 1995) using the following solvents: n-hexane/ ethyl acetate, 78/22 (v/v); and n-hexane/ethyl acetate, $75 / 15(\mathrm{v} / \mathrm{v})$.

DNA base composition. DNA was extracted as described by Charbonnier et al. (1992). RNase $\left(20 \mu \mathrm{g} \mathrm{ml}^{-1}\right)$ was added to the DNA for $1 \mathrm{~h}$ at $37^{\circ} \mathrm{C}$, and the DNA was dialysed overnight at $4{ }^{\circ} \mathrm{C}$ in TE buffer $(10 \mathrm{mM}$ Tris $/ \mathrm{HCl}, 1 \mathrm{mM}$ EDTA, pH 8.0). The $\mathrm{G}+\mathrm{C}$ content $(\mathrm{mol} \%)$ of the DNA was determined from the melting point in $0.1 \times$ SSC according to Marmur \& Doty (1962) using Escherichia coli DNA ( $57 \mathrm{~mol} \% \mathrm{G}+\mathrm{C}$; Sigma) as standard.

165 rRNA gene sequence analysis. The $16 \mathrm{~S}$ rRNA gene was amplified by PCR as previously described (Reysenbach \& Pace, 1995). The double-stranded PCR products were sequenced by cycle sequencing and an ABI 373 automated sequencer. The $16 \mathrm{~S}$ rRNA sequence was manually aligned with a subset of sequences from the Ribosomal Database Project (RDP) (Maidak et al., 1996), recent GenBank sequence releases and unpublished sequences. The secondary structure was used as a guide so that only homologous sequences were compared and to check for chimeric structures. The phylogenetic trees were constructed using either the evolutionary distance matrix with the algorithm of DeSoete (1983) or by maximum-likelihood analysis with FASTDNAML (Olsen et al., 1994). Bootstrap values were determined for the maximum-likelihood trees with 100 replicates.

DNA-DNA hybridization. The S1 nuclease method (Grimont et al., 1980) of quantitative DNA-DNA hybridizations was performed as described by Popoff \& Coynault (1980) on type DE81 filters (Whatman). DNA concentration and purity were estimated spectrophotometrically with Genequant II (Pharmacia). The DNA probes were labelled using a Nick Translation kit (Amersham). The hybridizations were performed at $65^{\circ} \mathrm{C}\left(25^{\circ} \mathrm{C}\right.$ below melting temperature $=$ optimal conditions) for $24 \mathrm{~h}$ in $0.42 \mathrm{M} \mathrm{NaCl}$. Levels of DNA-DNA homology were also determined by the DSMZ 
by measuring the rates of reassociation of pairs of singlestranded sheared DNA samples.

\section{RESULTS}

\section{Enrichment and purification}

One sample of an external layer of a vent chimney resulted in growth in both enrichment media after $45 \mathrm{~h}$ incubation under $40 \mathrm{MPa}$ hydrostatic pressure at $95^{\circ} \mathrm{C}$. Six other samples showed no growth after at least 1 week of incubation. Positive enrichments consisted of dense populations of coccoid cells. Samples incubated under atmospheric pressure in serum bottles at $95{ }^{\circ} \mathrm{C}$ did not grow. Subcultures grown on Thermatoga medium and under $40 \mathrm{MPa}$ pressure could not be successfully maintained. Enrichments on YPS-20 medium were successfully subcultured at $95^{\circ} \mathrm{C}$ and purified by a series of dilutions to extinction. Subcultures did not grow at $95^{\circ} \mathrm{C}$ at atmospheric pressures. The purified isolate $\left(\mathrm{MP}^{\mathrm{T}}\right)$ was stored at $4{ }^{\circ} \mathrm{C}$ under $35 \mathrm{MPa}$ hydrostatic pressure.

The isolate was diluted on plates containing YPS solid medium containing $2 \%(\mathrm{w} / \mathrm{v})$ Gelrite. Colonies were observed after $3 \mathrm{~d}$ incubation at $85^{\circ} \mathrm{C}$. One colony was subcultured into liquid culture to obtain biomass for protein extraction. Protein profiles of cell extracts from this culture and the $\mathrm{MP}^{\mathrm{T}}$ isolate were compared to verify if the purity of the strain isolated under high pressure was successful. Both cultures showed identical protein patterns (data not shown) indicating that purification was successful.

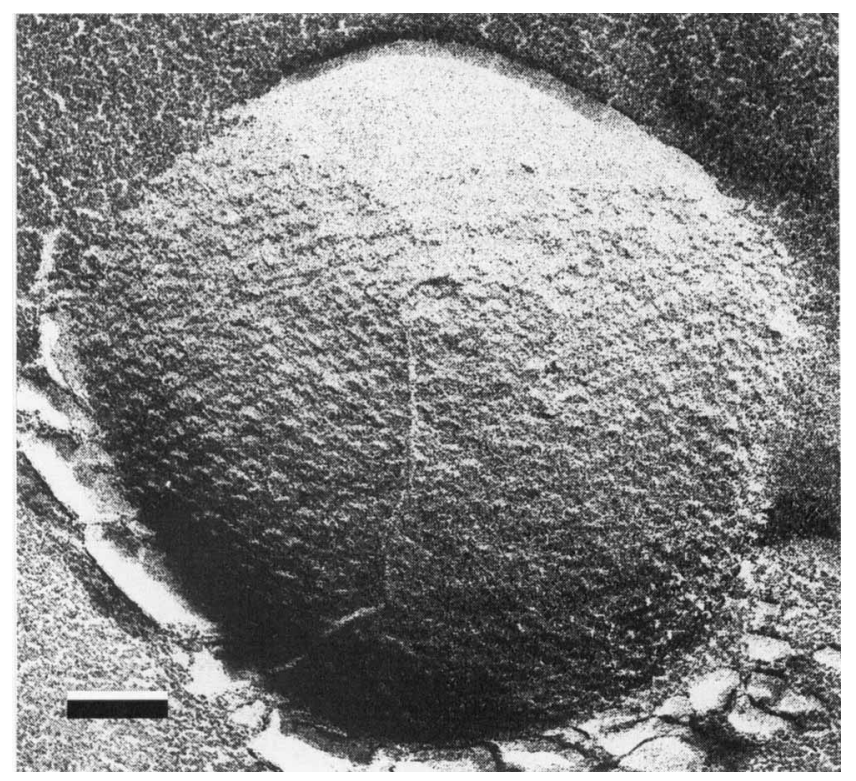

Fig. 1. Micrograph of a freeze-etched and metal shadowed cell of Thermococcus barophilus strain MP' showing the hexagonal 5 -layer lattice. Cells were grown in YPS medium at $85^{\circ} \mathrm{C}$ under atmospheric pressure. Bar, $100 \mathrm{~nm}$.
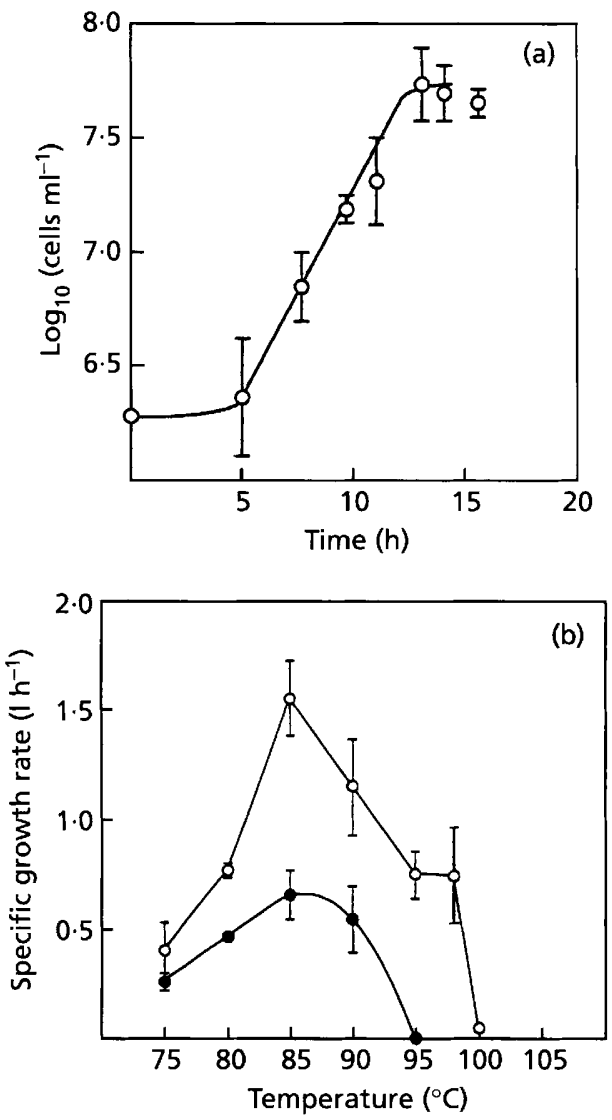

Fig. 2. (a) Growth of strain $\mathrm{MP}^{\top}$ at $85^{\circ} \mathrm{C}$ with $40 \mathrm{MPa}$ hydrostatic pressure. Four syringes were used for each timepoint and interrupted once for sampling. Growth rates were calculated from linear regression analysis along the logarithmic portion of the growth curves with error bars at $95 \%$ confidence. (b) Effect of temperature and hydrostatic pressure on the specific growth rate of strain MP'. The cells were grown in YPS-20 medium under $0.3 \mathrm{MPa}(O)$ and $40 \mathrm{MPa}(O)$ hydrostatic pressure as described in the Methods. Growth rates were calculated by performing linear regression analysis along the logarithmic part of the growth curves. Error bars $(95 \%$ confidence interval) of specific growth rates are shown when results of more than two separate experiments were available.

Enrichment attempts for micro-organisms under $40 \mathrm{MPa}$ hydrostatic pressure at $110^{\circ} \mathrm{C}$ were unsuccessful.

\section{Morphology}

Electron microscopy and phase-contrast microscopy (data not shown) revealed that cells were regular to slightly irregular motile cocci and occurred singly, in pairs or in small aggregates. The cell size ranged from 0.8 to $2.0 \mu \mathrm{m}$. Occasional atypical sizes and shapes and giant cells, sometimes more than $5 \mu \mathrm{m}$ in diameter, were observed. Cells appeared to divide by constriction. Freeze-fracturing (Fig. 1) of intact cells showed that the organisms were completely covered with a hexagonally arranged S-layer lattice (for a review see Sleytr et al., 1996) with centre-to-centre spacings 

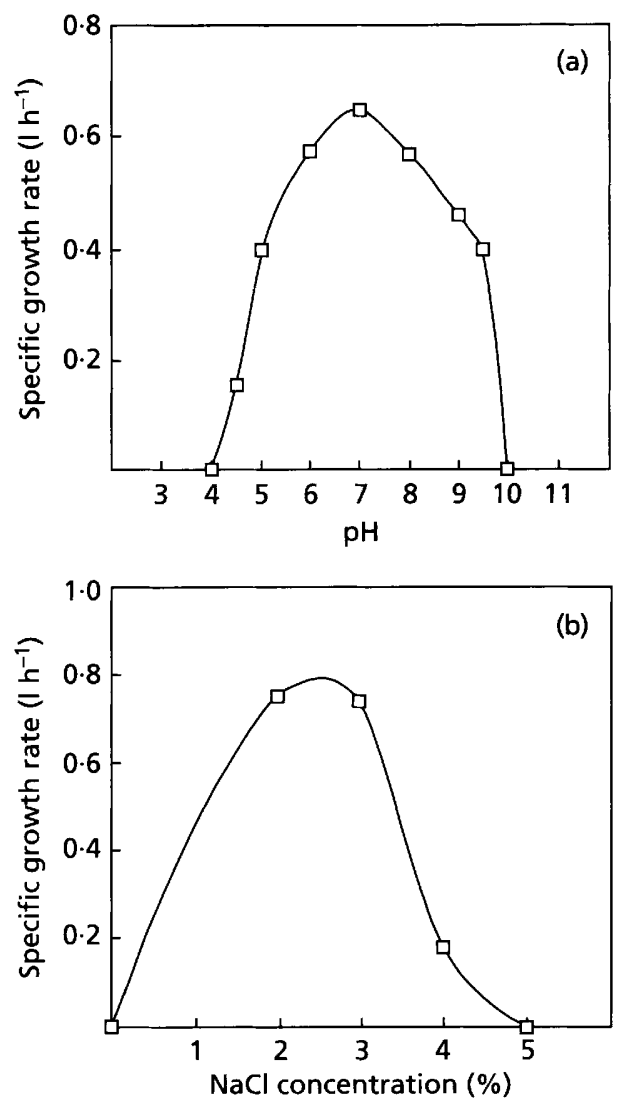

Fig. 3. $\mathrm{pH}$ and $\mathrm{NaCl}$ concentration optima for growth of isolate $M P^{\top}$ on YPS medium at $85^{\circ} \mathrm{C}$ under atmospheric pressure. Specific growth rates were plotted as a function of (a) $\mathrm{pH}$ (in the presence of $2.3 \%, w / v, N a C l)$ and (b) salinity $(\mathrm{pH} \mathrm{6.8)}$. Growth rates were calculated from linear regression analysis along the logarithmic part of the growth curves.

between the morphological units of approximately $28.4 \mathrm{~nm}$.

\section{Growth at different temperatures and pressures}

Strain $\mathrm{MP}^{\mathrm{T}}$ grew up to $100{ }^{\circ} \mathrm{C}$ under high hydrostatic pressure, while the upper temperature limit was $95^{\circ} \mathrm{C}$ under both low hydrostatic and atmospheric pressure conditions. The isolate required hydrostatic pressure $(15 \cdot 0-17.5 \mathrm{MPa})$ to grow above $95^{\circ} \mathrm{C}$. The growth rate increased at all temperatures tested when cells grew under high-pressure conditions. The optimum growth temperature was $85^{\circ} \mathrm{C}$ under both high- and lowpressure conditions (Fig. 2a, b), but the growth rate was at least double under high pressure than under low pressure (doubling times approx. 28 and $63 \mathrm{~min}$, respectively). The minimal temperature for growth at atmospheric pressure was $48^{\circ} \mathrm{C}$, but that limit was not estimated under high-pressure conditions.

\section{Determination of growth parameters}

Growth was observed at $\mathrm{pH} 4 \cdot 5-9 \cdot 5$ and the optimum $\mathrm{pH}$ was about 7.0. No growth was observed at $\mathrm{pH} 4 \cdot 0$ and $10 \cdot 0$ (Fig. 3a). The strain required $\mathrm{NaCl}$ for growth and growth was observed at salt concentrations of $1-4 \%(\mathrm{w} / \mathrm{v}) \mathrm{NaCl}$. The optimum salt concentration for growth was between 2 and $3 \%(\mathrm{w} / \mathrm{v})$ and the maximal salt concentration was less than $5 \%(\mathrm{w} / \mathrm{v})$ (Fig. 3b).

\section{Determination of growth requirements}

Strain $\mathrm{MP}^{\mathrm{T}}$ appeared to be an obligate heterotroph. No growth was detected in minimal medium amended with vitamins and with a $\mathrm{H}_{2} / \mathrm{CO}_{2}(80: 20)$ headspace. Optimal growth requirements were determined in the presence of $\mathrm{S}^{\circ}$, although $\mathrm{S}^{\circ}$ was not required for growth and could be replaced by cystine. Yeast extract and peptone could be replaced by several complex substrates, such as tryptone, beef extract, casein, Casamino acids, yeast extract or peptone. Pyruvate and propionate supported poor growth. Other substrates tested, such as starch, maltose, glycogen, sucrose, glucose and acetate, did not give any growth. The strain grew best with $\mathrm{NH}_{4} \mathrm{Cl}$ as a nitrogen source, but some growth occurred with thiourea, glutamate, $\mathrm{KNO}_{3}$ and $\mathrm{KNO}_{2}$.

\section{Antibiotic susceptibility}

The new isolate was insensitive to penicillin and streptomycin at a concentration of $150 \mu \mathrm{g} \mathrm{ml}^{-1}$, but it was sensitive to chloramphenicol and rifampicin at that concentration. The control bacterium T. maritima exhibited the expected pattern of antibiotic susceptibility at $80^{\circ} \mathrm{C}$, demonstrating that the antibiotics were not inactivated by heat.

\section{Lipid composition}

The complex lipid pattern of isolate $\mathrm{MP}^{\mathrm{T}}$ was analysed by TLC (data not shown). One major phospholipid $\left(R_{F} 0.34\right)$ was detected. A minor phospholipid, which was slightly $\alpha$-naphthol-positive suggesting the possible presence of a glycolipid, was also detected. TLC analysis of the hydrolysed complex lipids showed a major archaeol component, but no caldarchaeol was detected. The archaeol had $R_{F}$ values of 0.74 and 0.80 in n-hexane/ethyl acetate (78/22) and n-hexane/ethyl acetate $(75 / 15)$, respectively.

\section{DNA base composition}

The $\mathrm{G}+\mathrm{C}$ content of the DNA of isolate $\mathrm{MP}^{\mathrm{T}}$ determined by the thermal denaturation method was $37 \cdot 1 \mathrm{~mol} \%$.

\section{S rRNA sequence analysis}

Fig. 4 shows the phylogenetic relationship of strain $\mathrm{MP}^{\mathrm{T}}$ with other members of the Thermococcales. The levels of similarity (\%) between the 16S rRNA of $\mathrm{MP}^{\mathrm{T}}$ and the 16S rRNAs of other Thermococcus species (accession numbers of the sequences used in this analysis are given in parentheses) are as follows: Thermococcus sp. strain ES1 (U82238), 98.6; Thermo- 


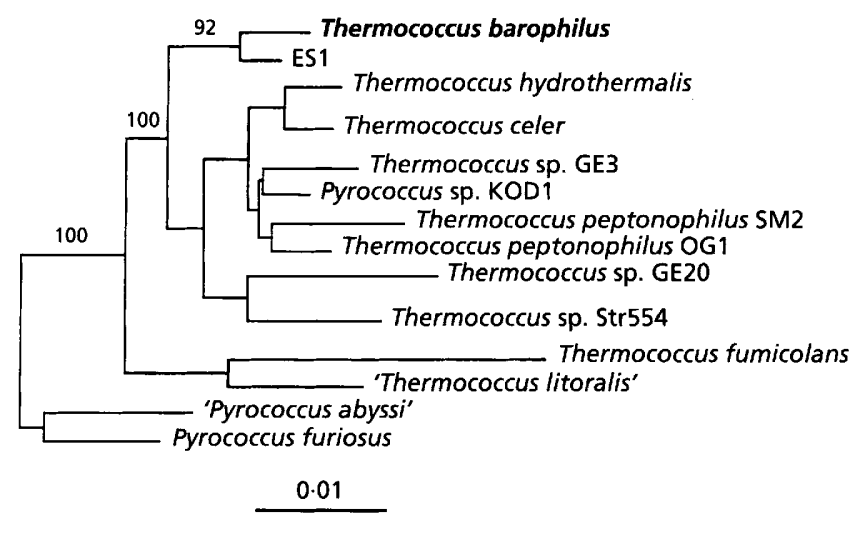

Fig. 4. Phylogenetic relationship of $T$. barophilus based on maximum-likelihood analysis of the 165 rRNA sequences. The bar represents the expected number of changes per sequence position.

coccus hydrothermalis (Z70244), 97.5; Thermococcus celer (M21529), 97.9; Thermococcus sp. GE3 (Z70245), 98.1; Pyrococcus sp. strain KOD1 (D38650), 97.7; Thermococcus peptonophilus SM2 (D37983), 97.3; T. peptonophilus OG1 (D37982), 97.8; Thermococcus sp. GE20 (Z70251), 97.0; Thermococcus sp. Str554 (Z70249), 97·3; Thermococcus fumicolans (Z70250), 95.5; 'T. litoralis' (Z70252), 97.3; 'Pyrococcus abyssi' (L19921), 96.7; and Pyrococcus furiosus (U20163), 96.7. Maximum-likelihood analysis and phylogenetic analysis using a distance matrix gave similar results. The new strain, designated Thermococcus barophilus, is closely related to the strain ES1. Bootstrap analysis confirmed this relationship.

\section{DNA-DNA hybridization}

The phylogenetic analysis of the 16S rRNA genes sequences (above) revealed that the strain belongs to the Thermococcales. Strain MP ${ }^{T}$ exhibited DNADNA homologies of $68.9 \%$ for ' $T$. litoralis' as determined by the filter method and $68 \%$ as determined by the spectrophotometric method performed by the DSMZ. The MPT isolate had $48 \%$ DNA hybridization to DNA from ' $P$. abyssi'.

\section{DISCUSSION}

The presence of ether lipids confirmed the archaeal nature of the novel barophilic, hyperthermophilic strain $\mathrm{MP}^{\mathrm{T}}$ and, based on composition of $16 \mathrm{~S}$ rRNA sequence, strain $\mathrm{MP}^{\mathrm{T}}$ belongs to the genus Thermococcus (Zillig et al., 1987). This classification is consistent with the morphological and physiological characteristics of strain $\mathrm{MP}^{\mathrm{T}}$, which are similar to those of this genus. The different physiological characteristics of some Thermococcus species, which have similar $\mathrm{G}+\mathrm{C}$ contents to strain $\mathrm{MP}^{\mathrm{T}}$, are summarized in Table 1.
The members of the genus Thermococcus can be divided into two groups based on their $\mathrm{G}+\mathrm{C}$ content. One group contains at least seven described species with high $\mathrm{G}+\mathrm{C}$ values $(50-60 \mathrm{~mol} \%$ ), and the other group contains three described species, ' $T$. litoralis', Thermococcus alcaliphilus and Thermococcus chitonophagus $(\mathrm{G}+\mathrm{C}$ contents of $38,42.4$ and $46.5 \mathrm{~mol} \%$, respectively). On the basis of its low $\mathrm{G}+\mathrm{C}$ content $(37.1 \mathrm{~mol} \%)$, the new strain could be related to the latter group. However, there are some physiological characteristics, phenotypic patterns and phylogenetic relationships which distinguish the new isolate from the members of this group. DNA-DNA hybridization experiments showed low similarity of strain $\mathrm{MP}^{\mathrm{T}}$ to ' $T$. litoralis'. Moreover, similarity between the $16 \mathrm{~S}$ rRNA of strain $\mathrm{MP}^{\mathrm{T}}$ and the 16S rRNA of other Thermococcus species used in the phylogenetic relationship was less than $98 \%$, except for Thermococcus strain ES1, whose $16 \mathrm{~S}$ rRNA was $98.6 \%$ similar to that of $\mathrm{MP}^{\mathrm{T}}$. Nevertheless, $\mathrm{MP}^{\mathrm{T}}$ could be distinguished from strain ES1 by several parameters (Table 1). The $\mathrm{G}+\mathrm{C}$ content of the two strains differed by more than $21 \%$, which is indicative of different species (Johnson, 1994). Strain $\mathrm{MP}^{\mathrm{T}}$ grew optimally at about $85^{\circ} \mathrm{C}$, pH 7.0 and with $25 \mathrm{~g} \mathrm{l}^{-1} \mathrm{NaCl}$ in the medium, whereas ES1 grew optimally at about $82^{\circ} \mathrm{C}, \mathrm{pH} 6.5$ and at 6-20 $\mathrm{g} \mathrm{l}^{-1} \mathrm{NaCl}$ (Pledger et al., 1994). Strains $\mathrm{MP}^{\mathrm{T}}$ and ES1 have different growth responses to pressure. MP $^{\mathrm{T}}$ was barophilic at all temperatures tested, while ES1 was not. ES1 only grew at $93{ }^{\circ} \mathrm{C}$ if pressurized at $22 \mathrm{MPa}$, and exhibited a barophilic response at $91{ }^{\circ} \mathrm{C}$ under 22 and $44 \mathrm{MPa}$. Moreover, ES1 was barosensitive at $85^{\circ} \mathrm{C}$. However, $\mathrm{MP}^{\mathrm{T}}$ was barophilic at all temperatures and was an obligate barophile at $95-100{ }^{\circ} \mathrm{C}$. Furthermore, the new isolate showed the highest growth ratio (twofold difference) between high and low hydrostatic pressure that has been reported for thermophilic organisms. The optimum growth temperature for $\mathrm{MP}^{\mathrm{T}}$ did not change with pressure (Fig. 2b).

Most of the deep-sea thermophiles isolated to date have been obtained at depths of $2000-3000 \mathrm{~m}$ and do not show barophilic responses under hydrostatic pressures at all temperatures tested, with the exception of ' $P$. abyssi' (Erauso et al., 1993). Psychrophilic isolates obtained at $3584 \mathrm{~m}$ and deeper are barophilic at all temperatures in their growth range (Yayanos, 1986). However, strain $\mathrm{MP}^{\mathrm{T}}$ was obtained from a depth of $3550 \mathrm{~m}$ and showed a similar pressure response to those reported for psychrophilic barophiles. Moreover, $\mathrm{MP}^{\mathrm{T}}$ was an obligate barophile above the temperature permitting growth at atmospheric pressure (Fig. 2b).

On the basis of the complex lipid pattern and core lipids, strain $\mathrm{MP}^{\mathrm{T}}$ resembles $T$. celer more than any other Thermococcus species. De Rosa et al. (1987) reported that the phospho-myo-inositol derivative of archaeol is the major component in $T$. celer and that caldarchaeol was not found. However, other Thermococcus species appear to synthesize caldarchaeol in 
Thermococcus barophilus sp. nov.

Table 1. Characteristics of Thermococcus species with low $G+C$ content, strain ES1 and the new isolate MPT

\begin{tabular}{|c|c|c|c|c|c|c|c|c|c|}
\hline \multirow[t]{2}{*}{ Strain } & \multirow{2}{*}{$\begin{array}{c}G+C \text { content } \\
(\mathrm{mol} \%)\end{array}$} & \multirow[t]{2}{*}{ Origin } & \multirow{2}{*}{$\underset{\text { optimum }}{\text { pH }}$} & \multicolumn{2}{|c|}{ Growth temperature $\left({ }^{\circ} \mathrm{C}\right)$} & \multicolumn{2}{|c|}{$\mathrm{NaCl}\left(\mathrm{g} \mathrm{I}^{-1}\right)$} & \multirow{2}{*}{$\begin{array}{l}\text { Barophilic } \\
\text { response }\end{array}$} & \multirow[t]{2}{*}{ Reference } \\
\hline & & & & Range & Optimum & Range & Optimum & & \\
\hline 'Thermococcus litoralis' DSM 5474 & $38 \cdot 0$ & $\begin{array}{l}\text { Sediment of shallow marine } \\
\text { solfatara, Italy }\end{array}$ & $7 \cdot 2$ & $65-95$ & 88 & $18-65$ & 25 & ND & Neuner et al. (1990) \\
\hline Thermococcus chitonophagus DSM $10152^{\mathrm{T}}$ & $46 \cdot 5$ & $\begin{array}{l}\text { Smoker fragments, collected at } \\
\text { Guaymas Basin }(2000 \mathrm{~m})\end{array}$ & 6.7 & $60-93$ & 85 & $8-80$ & 20 & ND & Huber et al. (1995) \\
\hline Thermococcus alcaliphilus DSM $10322^{\mathrm{T}}$ & $42 \cdot 4$ & $\begin{array}{l}\text { Shallow marine hydrothermal } \\
\text { system, Italy }\end{array}$ & $9 \cdot 0$ & $56-90$ & 85 & $10-60$ & $20-30$ & ND & Keller et al. (1995) \\
\hline Thermococcus sp. strain ES1 & $58 \cdot 6$ & $\begin{array}{l}\text { Polychaete worm, Juan de Fuca } \\
\text { Ridge }(2200 \mathrm{~m})\end{array}$ & $6 \cdot 5$ & $54-91$ & 82 & $6-40$ & $6-20$ & + & Pledger \& Baross (1991) \\
\hline Thermococcus sp. strain $\mathrm{MP}^{\mathrm{T}}$ & $37 \cdot 1$ & Chimney wall, Snakepit $(3550 \mathrm{~m})$ & $7 \cdot 0$ & $48-100$ & 85 & 1040 & $20-30$ & + & This study \\
\hline
\end{tabular}

ND, Not determined.

addition to archaeol (Antoine et al., 1995; Canganella et al., 1997; Huber et al., 1995). T. alcaliphilus and T. chitonophagus both produce tetraethers (caldarchaeol), but $T$. chitonophagus has one cyclopentane ring as well (Huber et al., 1995; Keller et al., 1995). The archaeols from $T$. chitonophagus were reported at $R_{F}$ values of 0.75 and 0.62 (Huber et al., 1995), while in $\mathrm{MP}^{\mathrm{T}}$ the archaeols were at $R_{F}$ values of 0.74 and 0.80 . Moreover, the presence of glycolipids in strain $\mathrm{MP}^{\mathrm{T}}$ is unusual in Thermococcus species and has not been observed before in this genus. The possible presence of glycolipids must be confirmed by spectroscopic analyses of a pure compound.

The cell envelope of $T$. barophilus has an unusual Slayer lattice constant of $28.4 \mathrm{~nm}$ which is much higher than other values found within Thermococcus species. For instance, both T. alcaliphilus and T. chitonophagus have a much lower lattice constant of around $15 \mathrm{~nm}$ (Huber et al., 1995; Keller et al., 1995).

On the basis of its physiological characteristics and phylogenetic relationships, the new isolate represents a new species of Thermococcus. This species is named Thermococcus barophilus because it grows best under high hydrostatic pressures.

\section{Description of Thermococcus barophilus Marteinsson, Birrien and Prieur sp. nov.}

Thermococcus barophilus (bar.o'phi.lus. Gr. neutr. n. bar weight; Gr. adj. philos loving; M.L. adj. barophilus weight lover, referring to the weight of the water column).

Cells are regular to irregular cocci and variable in size (usually $0 \cdot 8-2 \cdot 0 \mu \mathrm{m}$ ). The cell envelope consists of a hexagonal S-layer lattice (spacing $28 \cdot 4 \mathrm{~nm}$ ). Cell division occurs by constriction. Obligate anaerobe. Grows optimally at $2-3 \%(\mathrm{w} / \mathrm{v}) \mathrm{NaCl}$ and $\mathrm{pH} 7 \cdot 0$. At atmospheric pressure, growth occurs at $48-95^{\circ} \mathrm{C}$, with optimum growth temperature at $85^{\circ} \mathrm{C}$ under $0.3 \mathrm{MPa}$ hydrostatic pressure. High hydrostatic pressure $(40 \mathrm{MPa})$ stimulates growth at $75,80,85,90$ and $95^{\circ} \mathrm{C}$ with an optimum growth temperature of $85^{\circ} \mathrm{C}$. Obligately barophilic between 95 and $100^{\circ} \mathrm{C}$ and requires $15 \cdot 0-17 \cdot 5 \mathrm{MPa}$ to grow at these temperatures.
Obligately chemo-organotrophic. Grows on complex organic compounds. Sulfur is not necessary for growth, but greatly enhances growth and can be replaced by cystine. Membrane lipids are composed of one major phospholipid and an archaeol component. The $\mathrm{G}+\mathrm{C}$ content is $37 \cdot 1 \mathrm{~mol} \%$. 16S rRNA sequence comparisons place Thermococcus barophilus in the Thermococcales. Isolated from a chimney wall, under $40 \mathrm{MPa}$ hydrostatic pressure at $95^{\circ} \mathrm{C}$, from the MidAtlantic Ridge, Snakepit at depth of $3550 \mathrm{~m}$. The type strain is Thermococcus barophilus $\mathrm{MP}^{\mathrm{T}}$ [CNCM I-1946 (Collection Nationale de Cultures de Microorganismes, Institut Pasteur, Paris, France)].

\section{ACKNOWLEDGEMENTS}

We thank Aline Fiala-Medioni and Cindy Van Dover, chief scientists of the 'MAR93' cruise organized by INSU and WHOI, for inviting two of the authors to participate in the 'MAR93' expedition. We thank Mr Eduardo Pagnotta for technical assistance for lipid analysis and E. Corre and P. Rivera for help with 16S rRNA sequence analysis. We are grateful to Andrea Scheberl and Monika Miksa for technical assistance in electron microscopy which was supported in part by grants from the Austrian Science Foundation, project S7201-MOB and the Federal Ministry of Science and Transportation. V.T.M. was supported by a FrenchIcelandic fellowship (Programme Franco-Islandais). This work was supported by GDR 1006 CNRS/IFREMER and the CPER 94-95 (Contrat de Plan Etat-Région). European Union (Feder, objectif 5b) and Conseil Général du Finistèr.

\section{REFERENCES}

Antoine, E., Guezennec, J., Meunier, J. R., Lesonguer, F. \& Barbier, G. (1995). Isolation and characterization of extremely thermophilic archaebacteria related to the genus Thermococcus from deep-sea hydrothermal Guaymas Basin. Curr Microbiol 31, 186-192.

Balch, W. \& Wolfe, R. S. (1976). New approach to the cultivation of methanogenic bacteria: 2-mercaptoethanesulfonic acid (HSCoM)-dependent growth of Methanobacterium ruminantium in a pressurized atmosphere. Appl Environ Microbiol 32, 781-791.

Canganella, F. W., Jones, J., Gambacorta, A. \& Antranikian, G. (1997). Thermococcus guamasii sp. nov. and Thermococcus aggregans sp. nov., two novel thermophilic archaea isolated from the Guaymas basin hydrothermal vent site. Arch Microbiol 167, 233-238. 
Charbonnier, F., Erauso, G., Barbeyron, T., Prieur, D. \& Forterre, P. (1992). Evidence that a plasmid from a hyperthermophilic archaebacterium is relaxed at physiological temperatures. $J$ Bacteriol 174, 6103-6108.

Deming, J. W. \& Baross, J. A. (1993). Deep-sea smokers: windows to a subsurface biosphere? Geochim Cosmocim Acta 57, 3219-3229.

De Rosa, M. \& Gambacorta, A. (1994). Archaeal lipids. In Chemical Methods in Prokaryotic Systematics, pp. 199-264. Edited by M. Goodfellow \& A. G. O'Donnell. Chichester: Wiley.

De Rosa, M., Gambacorta, A., Nicolaus, B., Chappe, B. \& Albrecht, P. (1983). Isoprenoid ethers, backbone of complex lipids of the archaebacterium Sulfolobus solfataricus. Biochim Biophys Acta 753, 249-256.

De Rosa, M., Gambacorta, A., Trincone, A., Basso, A., Zillig, W. \& Holz, I. (1987). Lipids of Thermococcus celer, a sulfur-reducing archaebacterium: structure and biosynthesis. Syst Appl Microbiol 9, 1-5.

DeSoete, G. (1983). A least squares algorithm for fitting additive trees to proximity data. Psychometrika 48, 621-626.

Erauso, G., Reysenbach, A. L., Godfroy, A., Meunier, J. R., Crump, B., Partensky, F., Baross, J. A., Marteinsson, V., Barbier, G., Pace, N. R. \& Prieur, D. (1993). Pyrococcus abyssi sp. nov., a new hyperthermophilic archaeon isolated from a deep-sea hydrothermal vent. Arch Microbiol 160, 338-349.

Erauso, G., Prieur, D., Godfroy, A. \& Raguénès, G. (1995). Plate cultivation technique for strictly anaerobic, thermophilic, sulfur-metabolizing Archaea. In Archaea: a Laboratory Manual, pp. 25-29. Edited by F. T. Robb. Cold Spring Harbor, NY: Cold Spring Harbor Laboratory.

Grimont, P. A. D., Popoff, M. Y., Grimont, F., Coynault, C. \& Lemelin, M. (1980). Reproducibility and correlation study of three deoxyribonucleic acid hybridization procedures. Curr Microbiol 4, 337-442.

Holden, J. F. \& Baross, J. (1995). Enhanced thermotolerance by hydrostatic pressure in the deep-sea hyperthermophile Pyrococcus strain ES4. FEMS Microbiol Ecol 18, 27-34.

Huber, R., Langworthy, T. A., König, H., Thomm, M., Woese, C. R., Sleytr, U. B. \& Stetter, K. O. (1986). Thermotoga maritima sp. nov. represents a new genus of unique extremely thermophilic eubacteria growing up to $90^{\circ} \mathrm{C}$. Arch Microbiol 144, 324-333.

Huber, R., Stöhr, J., Honenhaus, S., Rachel, R., Burggraf, S., Jannasch, H. W. \& Stetter, K. O. (1995). Thermococcus chitonophagus sp. nov., a novel, chitin-degrading hyperthermophilic archaeum from deep-sea hydrothermal environment. Arch Microbiol 164, 255-264.

Jannasch, H. W. \& Wirsen, C. O. (1984). Variability of pressure adaptation in deep-sea bacteria. Arch Microbiol 139, 281-288.

Jannasch, H. W., Wirsen, C. O., Molyneaux, S. J. \& Langworthy, T. A. (1992). Comparative physiological studies of hyperthermophilic archaea isolated from deep-sea hydrothermal vents. Appl Environ Microbiol 58, 3472-3481.

Johnson, J. L. (1994). Similarity analysis of DNAs. In Methods for General and Molecular Bacteriology, pp. 655-682. Edited by P. Gerhardt, R. G. E. Murray, W. A. Wood \& N. R. Krieg. Washington, DC: American Society for Microbiology.

Keller, M., Braun, F.-J., Dirmeieir, R., Hafenbradl, D., Burggraf, S., Rachel, R. \& Stetter, K. O. (1995). Thermococcus alcaliphilus sp. nov., a new hyperthermophilic archaeum growing on polysulfide at alkaline pH. Arch Microbiol 164, 390-395.
Laemmli, U. K. (1970). Cleavage of structural proteins during the assembly of the head of bacteriophage T4. Nature 227, 680-685.

Maidak, B. L., Olsen, G. J., Larsen, N., Overbeek, R., McCaughey, M. J. \& Woese, C. R. (1996). The Ribosomal Database Project (RDP). Nucleic Acids Res 24, 82-85.

Marie, D., Vaulot, D. \& Partensky, F. (1996). Application of the novel nucleic acid dyes YOYO-1, YO-PRO-1, and PicoGreen for flow cytometric analysis of marine prokaryotes. Appl Environ Microbiol 62, 1649-1655.

Marmur, J. \& Doty, P. (1962). Determination of the base composition of deoxyribonucleic acid from its thermal denaturation temperature. J Mol Biol 5, 109-118.

Marteinsson, V. T., Watrin, L., Prieur, D., Caprais, J. C., Raguénès, G. \& Erauso, G. (1995). Phenotypic characterization, DNA similarities, and protein profiles of twenty sulfur-metabolizing hyperthermophilic anaerobic Archaea isolated from hydrothermal vents in the southwestern Pacific Ocean. Int J Syst Bacteriol 45, 623-632.

Marteinsson, V. T., Moulin, P., Birrien, J.-L., Gambacorta, A. Vernet, M. \& Prieur, D. (1997). Physiological responses to stress conditions and barophilic behaviour of the hyperthermophilic vent archaeon Pyrococcus abyssi. Appl Environ Microbiol 93 , $1230-1236$.

Miller, J. F., Shah, N. N., Nelson, C. M., Ludlow, J. M. \& Clark, D. S. (1988). Pressure and temperature effects on growth and methane production of the extreme thermophile Methanococcus jannaschii. Appl Environ Microbiol 54, 3039-3042.

Nelson, C. M., Schuppenhauer, M. R. \& Clark, D. S. (1991). Effect of hyperbaric pressure on a deep-sea archaebacterium in stainless steel and glass-linked vessels. Appl Environ Microbiol 57, 3576-3580.

Nelson, C. M., Schuppenhauer, M. R. \& Clark, D. S. (1992). Highpressure, high-temperature bioreactor for comparing effects of hyperbaric and hydrostatic pressure on bacterial growth. Appl Environ Microbiol 58, 1789-1793.

Neuner, A., Jannasch, H. W., Belkin, S. \& Stetter, K. O. (1990). Thermococcus litoralis sp. nov.: a new species of extremely thermophilic marine archaebacteria. Arch Microbiol 153, 205-207.

Olsen, G. J., Matsuda, H., Hagstrom, R. \& Overbeek, R. (1994). FASTDNAML: a tool for construction of phylogenetic trees of DNA sequences using maximum likelihood. Comput Appl Biosci 10, 41-48.

Pledger, R. J. \& Baross, J. A. (1991). Preliminary description and nutritional characterization of a chemoorganotrophic archaebacterium growing of up to $110^{\circ} \mathrm{C}$ isolated from a submarine hydrothermal vent environment. J Gen Microbiol 137, 203-211.

Pledger, R. J., Crump, B. C. \& Baross, J. A. (1994). A barophilic response by two hyperthermophilic hydrothermal vent archaea: an upward shift in the optimal temperature and acceleration of growth rate at supra-optimal temperature by elevated pressure. FEMS Microbiol Ecol 14, 233-242.

Pley, U., Schipka, J., Gambacorta, A., Jannasch, H. W., Fricke, H., Rachel, R. \& Stetter, K. O. (1991). Pyrodictium abyssi sp. nov. represents a novel heterotrophic marine archael hyperthermophilic growing at $110^{\circ} \mathrm{C}$. Syst Appl Microbiol 14, 245-253.

Popoff, M. Y. \& Coynault, C. (1980). Use of DEAE-cellulose filters in the $\mathrm{S} 1$ nuclease method for bacterial deoxyribonucleic acid hybridization. Ann Microbiol 131A, 151-155.

Prieur, D., Erauso, G. \& Jeanthon, C. (1995). Hyperthermophilic 
life at deep-sea hydrothermal vents. Planet Space Sci 43, 115-122.

Reysenbach, A.-L. \& Deming, J. W. (1991). Effects of hydrostatic pressure on growth of hyperthermophilic archaebacteria from Juan de fuca Ridge. Appl Environ Microbiol 57, 1271-1274.

Reysenbach, A.-L. \& Pace, N. R. (1995). Reliable amplification of hyperthermophilic archaeal $16 \mathrm{~S}$ rRNA genes by the polymerase chain reaction (PCR). In Archaea: a Laboratory Manual, pp. 101-105. Edited by F. T. Robb. Cold Spring Harbor, NY : Cold Spring Harbor Laboratory.

Sleytr, U. B., Messner, P. \& Pum, D. (1988). Analysis of crystalline bacterial surface layers by freeze-etching, metal-shadowing, negative staining and ultrathin sectioning. Methods Microbiol 20, 29-60.
Sleytr, U. B., Messner, P., Pum, D. \& Sàra, M. (1996). Crystalline Bacterial Cell Surface Proteins. Austin, TX: R. G. Landes.

Trincone, A., De Rosa, M., Gambacorta, A., Lanzotti, V., Nicolaus, B., Harris, J. E. \& Grant, W. D. (1988). A simple chromatographic procedure for the detection of cyclized archaebacterial glycerolbisdiphytanyl-glycerol-tetraether core lipids. J Gen Microbiol 134, 3159-3163.

Yayanos, A. A. (1986). Evolutional and ecological implications of the properties of deep-sea barophilic bacteria. Proc Natl Acad Sci USA 83, 9542-9546.

Zillig, W., Holtz, I., Klenk, H. P., Trent, J., Wunderl, S., Janekovic, D., Imsel, E. \& Haas, B. (1987). Pyrococcus woesei, sp. nov., an ultra-thermophilic marine archaebacterium, representing a novel order, Thermococcales. Syst Appl Microbiol 9, 62-70. 